\title{
How are the roofing and unroofing processes reflected in sandstone composition? -A case study in the Shimanto Belt, Kii Peninsula, southwestern Japan-
}

\author{
Takanori Bessho $^{1 *}$
}

\begin{abstract}
Multi-approach studies combining modal, heavy mineral and garnet analyses of sandstones have been carried out on the Late Cretaceous Terasoma Formation and the Palaeogene Otonashigawa Accretionary Sequence (AS) of the Shimanto Belt in the Kii Peninsula, Southwest Japan. Modal compositions of the Terasoma Formation change upward from feldspathic wacke to lithic wacke. Heavy mineral assemblages also change upward from the one rich in zircon and garnet with epidote, titanite and allanite to the one rich in euhedral zircon. The garnets from the Lower Member are mostly almandine, low and intermediate $\mathrm{P} / \mathrm{T}$ types with minor high $\mathrm{P} / \mathrm{T}$ type and grandite. In the Middle Member, the proportion of low $\mathrm{P} / \mathrm{T}$ type increases at the expense of high $\mathrm{P} / \mathrm{T}$ type and grandite garnets. These trends suggest that Coniacian violent felsic magmatism took place and their products thickly roofed the basement rocks. Modal compositions of the Haroku formation in the Otonashigawa AS change upward from lithic wacke to feldspathic arenite. The heavy mineral assemblages of the lower members are rich in zircon and garnet accompanied by allanite and greenish-brown hornblende. Sandstones of the uppermost member contain abundant epidote, allanite and titanite. The chemical compositions of detrital garnets also show a decreasing trend of the pyrope-rich almandine (intermediate $\mathrm{P} / \mathrm{T}$ type garnet) and an increasing trend of spessartine-rich almandine (low $\mathrm{P} / \mathrm{T}$ type garnet) from the lower to upper members. A few grandites were extracted from the uppermost horizon. These data suggest that felsic volcanic products and intermediate to high grade metamorphic rocks are the probable sources of the Otonashigawa AS. Due to the successive erosion, granitic, low P/T metamorphic rocks and calcareous metamorphic rocks were exposed to the surface. Roofing and unroofing processes are especially suggested by changes of the proportion of euhedral zircon, allanite, spessartine-rich almandine garnet (L), high $\mathrm{P} / \mathrm{T}$ garnet and grandite garnet.
\end{abstract}

Key words: detrital garnet chemical composition, heavy mineral composition, modal composition, sandstone, Shimanto Belt, roofing, unroofing

\section{Introduction}

Capacious felsic volcanism covering a large area with thick piles of volcanic products is known as roofing (Kumon, 1985). On the other hand, continuous erosion leading to exposure of rocks buried at depth is known as unroofing (Groves, 1931; Mansfield, 1979). Systematic study of modal composition of sandstones in a vertical succession can provide valuable clues to unravel the roofing and unroofing events in the provenance (Mansfield, 1979; Kumon, 1983, 1985; Kusunoki and Musashino, 1989;

Received: January 30, 2014; Accepted: May 12, 2015

1 Department of Geosciences, Graduate School of Science, Osaka City University, Osaka 558-8585, Japan

* Corresponding author: bessho@sci.osaka-cu.ac.jp
Oyaizu and Kiminami, 2004). Such changes in the source area can be substantiated from the nature and chemical composition of the heavy minerals present in the sandstones (Chaundhri, 1972; Obayashi, 1995; Udden and Lundberg, 1998).

The Shimanto Belt in the Kii Peninsula, southwestern Japan is composed of a number of accretionary prisms and forearc basin sediments (Terasoma Formation), ranging in age from late Early Cretaceous to Early Miocene. Multiple approaches comprising modal, heavy mineral assemblages and chemical composition of garnets of the sandstones have revealed the changes in the composition from the Late Cretaceous Terasoma Formation and the Palaeogene Otonashigawa Accretionary Sequence in the Shimanto Belt, and these changes have been attributed to a roofing and an 
unroofing in the hinterland (Bessho, 2004; Bessho and Nakaya, 2011). This paper deals with a case study of roofing and unroofing processes deduced from the heavy mineral assemblages and the chemical composition of garnets from the sandstones of the Shimanto Belt, adding more detailed chemical analyzed data of garnet than before (Bessho, 2000) in Terasoma Formation.

\section{Geological setting}

The Shimanto Belt, bordering the Chichibu Belt on the north by the Butsuzo Tectonic Line, extends from the Boso Peninsula to the Nansei Islands over a distance of $1800 \mathrm{~km}$. The stratigraphic studies of the Shimanto Belt in the Kii Peninsula have been advanced drastically and revised by a number of workers (Kishu Shimanto Research Group, 1968, 1970, 1977, 1983, 1986, 1991, 2006). Recently, tectono- stratigraphy of the Kii Peninsula has been revised on the concept of accretion tectonics (Suzuki and Nakaya, 2012). The Shimanto Belt in the Kii Peninsula is divided into the Kouyasan, Hidakagawa and Hikigawa Subbelts from north to south by Yanase Fault and Gobo-Totsukawa Thrust (Fig. 1). The Kouyasan Subbelt, a Cretaceous accretionary complex, is named the Hanazono accretionary complex in the western area (Yamamoto and Suzuki, 2012). The Hidakagawa Subbelt, which is an also Cretaceous accretionary complex, comprises three accretionary complexes (AC). These are Yukawa AC (Albian to Cenomanian), Miyama AC (Turonian to Early Maastrichtian) and Ryujin ACs (Late Campanian to Middle Maastrichian) from north to south. The Hikigawa Subbelt, a Paleogene accretionary prism, is composed mostly of clastic rocks with subordinate greenstones. These rocks are weakly deformed and maintain its primary stratigraphy, therefore, are called as the accre-

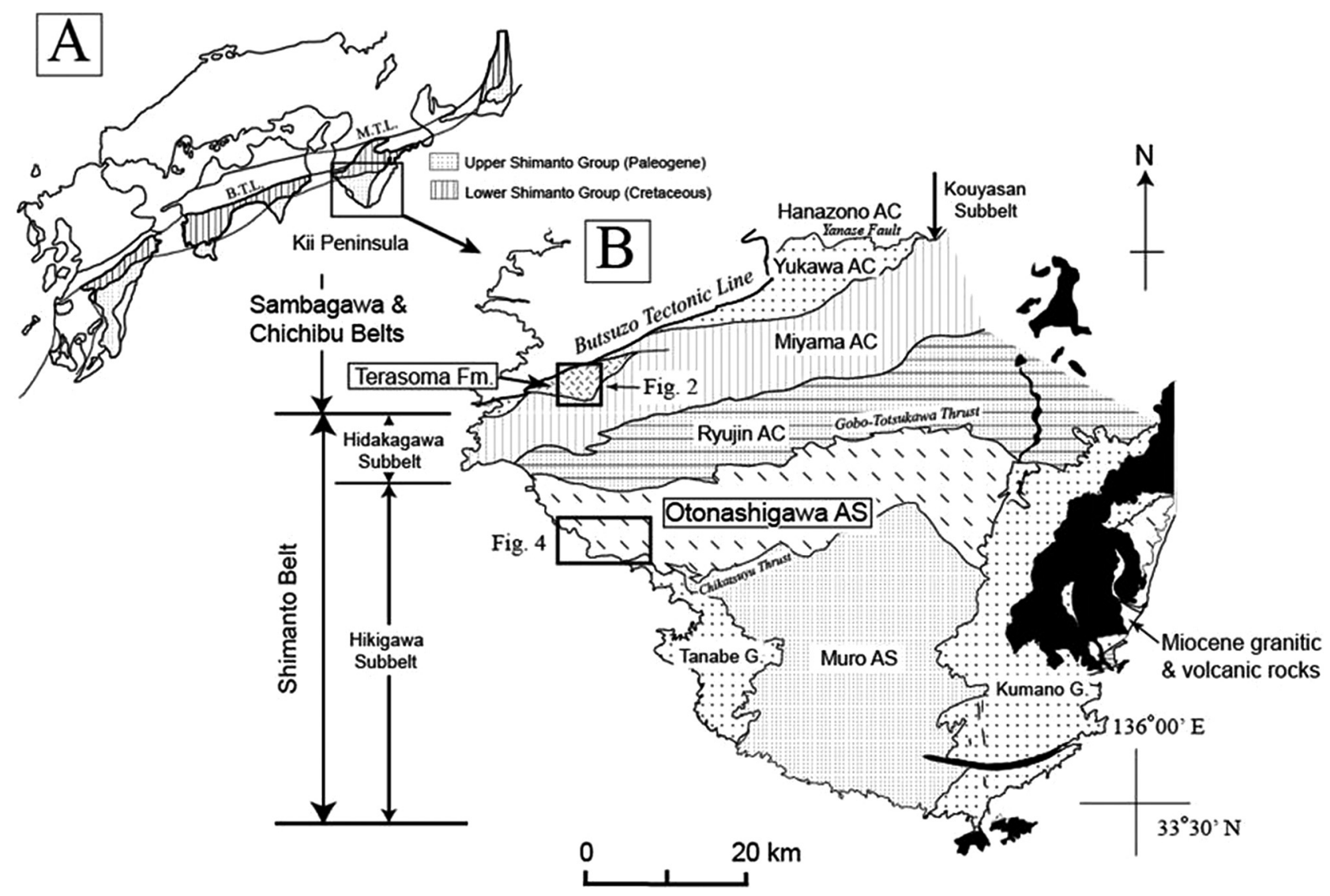

Fig. 1 (A) Geological sketch map of the Shimanto Belt in Southwest Japan; modified from Teraoka et al. (1999). (B) Subdivision of the Shimanto Accretionary Prism in the Kii Peninsula; modified from Suzuki and Nakaya (2012). B.T.L.: Butsuzo Tectonic Line, M.T.L.: Median Tectonic Line, AC: Accretionary Complex, AS: Accretionary Sequence, G.: Group and Fm.: Formation. 


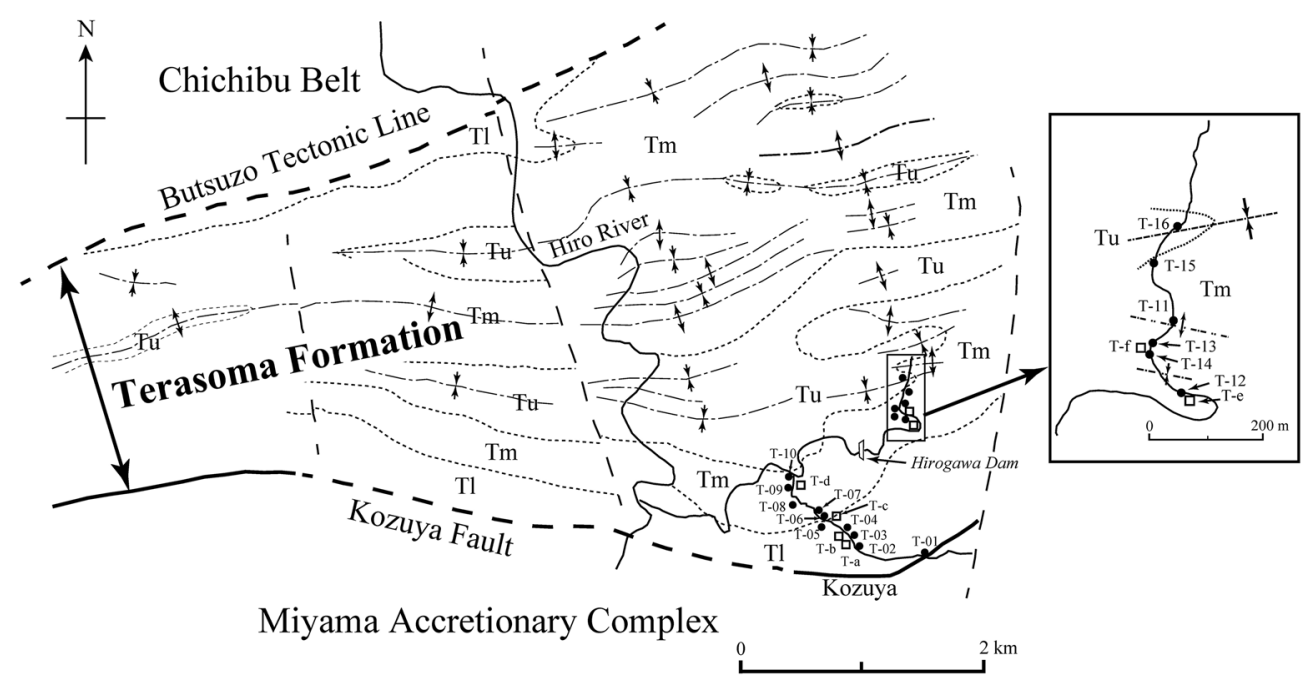

Fig. 2 Simplified geological map of the Terasoma Formation (Kishu Shimanto Research Group, 1983) and sampling locations of sandstones. Solid circles represent samples used for modal, heavy mineral and garnet chemical analyses and open squares show samples only used for garnet chemical analysis. Solid and dashed lines represent fault and inferred fault respectively. Tl: Lower Member, Tm: Middle Member and Tu: Upper Member.

tionary sequence (AS) (Suzuki and Nakaya, 2012). This Subbelt consists of the Otonashigawa (Paleocene to Early Eocene) and the Muro ASs (Middle Eocene to Early Miocene) (Fig. 1).

The Terasoma Formation (Turonian to Early Campanian) is situated in the northwestern margin of the Hidakagawa Subbelt (Fig. 1). Due to the presence of abundant megafossils like Inoceramid and Ammonites as well as coherent stratigraphy, it is believed to be deposited in a forearc basin. The formation is divided into three members, i.e., the Lower, Middle and Upper members (Figs. 2 and 3) (Kishu Shimanto Research Group, 1983). The Lower Member is composed mainly of shale, and shale-dominated alternating beds of sandstone and shale accompanied with pebbly shale and sandstone. The Middle Member consists of bedded sandstones with intercalated shale layers. The Upper Member comprises dominantly shale with subordinate sandy laminae.

The Otonashigawa AS extends in east - west direction as a long narrow belt in the northern margin of Hikigawa Subbelt (Fig. 1). On the basis of dominant lithology, the Otonashigawa AS is divided into the Uridani and Haroku Formations from bottom to top (Fig. 4) (Hatenashi Reseach Group, 1980). The Uridani Formation is composed of grey, green and red shale with insignificant greenstones. The Haroku Formation is subdivided into the Lower and Upper Members. The former is mainly composed of interbedded sand- stone and shale, and the latter consists of thick sandstone and conglomerate beds. The Haroku Formation forms thickening and coarsening-upward sequence (Fig. 5). The Otonashigawa AS has been interpreted as submarine fan deposit accumulated at the mouth of a submarine canyon debouched into a trench basin (Nakaya and Sakamoto, 2012).

\section{Methodology}

A total number of thirty fine- to medium-grained sandstone samples, sixteen from the Terasoma Formation and fourteen from the Otonashigawa AS were collected during field study (Figs. 3 and 5). Thin sections for modal analysis were made parallel to bedding plane. The modal compositions of sandstones were determined by point-counting method, counting 500 points per thin section under the polarized microscope following the traditional method of Kumon and Kiminami (1994). The sandstones were classified following the scheme of Okada (Okada, 1971).

The heavy mineral analysis was made following the method proposed by Sato and Suzuki (1991) modified by Bessho (1997). The finely-crushed sandstones were sieved on a standard sieve of 60 mesh $(250 \mu \mathrm{m})$ size and the heavy minerals were separated by gravity setting method using tetrabromoethane of specific gravity 2.97 as heavy liquid. The heavy mineral were mounted on a glass slide and identified under polarizing microscope by their diagnostic 


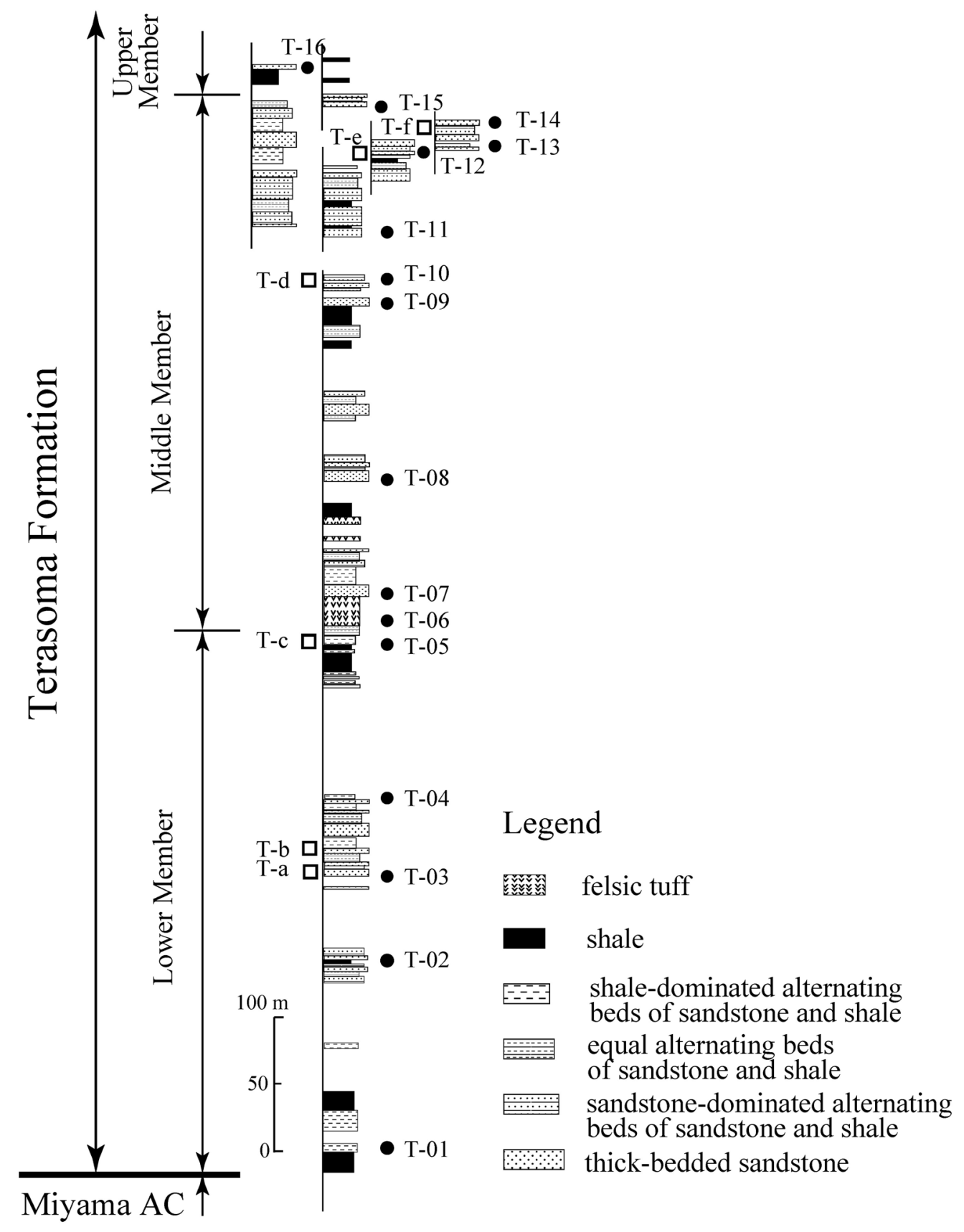

Fig. 3 Columnar sections of the Terasoma Formation along the sampling routes; modified from Bessho (2004). Marks of the sampling locations of sandstones are same as in Fig. 2.

optical characters. Identification of grains has been continued until the number of transparent heavy mineral attains about four hundred per slide. The non-transparent minerals were treated as opaque heavy minerals without detailed identification.
Detrital garnet grains were picked up from the heavy fraction under binocular microscope. Slides for chemical analysis were made following Adachi et al. (1995). Chemical analysis of garnets were made by energy dispersive spectrometer (JSM-5500) of Osaka City University, op- 


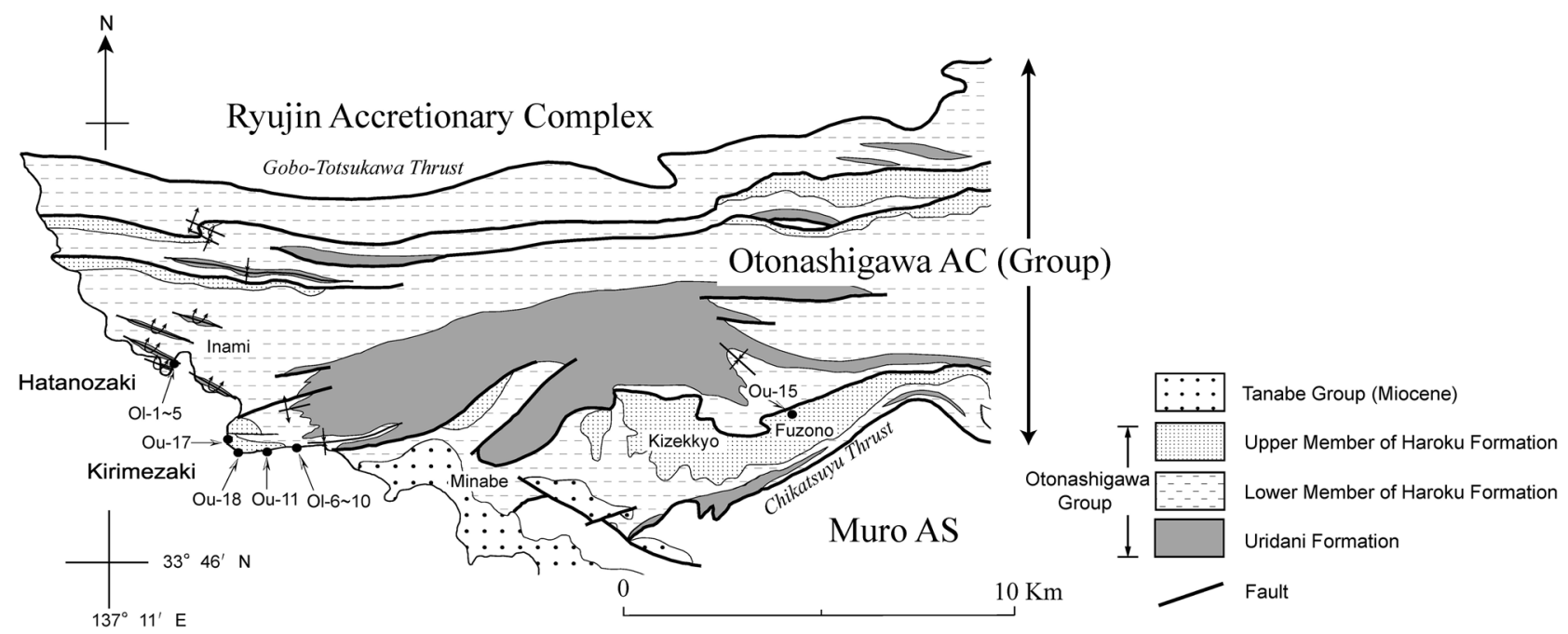

Fig. 4 Geological map of the Otonashigawa AS at western coastal region of the Kii Peninsula quoted from Nakaya (2006) and solid circles represent the sampling locations of sandstones.

erated under the condition of $20 \mathrm{kV}$ accelerating voltage, beam current of $5 \times 10^{-8} \mathrm{~A}$ and count time of $50 \mathrm{sec}$. Garnets were analyzed for 7 elements $\mathrm{Si}, \mathrm{Al}, \mathrm{Ti}, \mathrm{Fe}, \mathrm{Mn}, \mathrm{Mg}$ and $\mathrm{Ca}$. The ratio of $\mathrm{Fe}^{2+}$ and $\mathrm{Fe}^{3+}$ was calculated presuming garnet stoichiometry. The end-member calculations were made following Deer et al. (1992). A total number of 443 grains were analyzed from the Terasoma Formation, 249 grains in 3 samples from the Lower Member and 194 grains in 3 samples from the Middle Member (Fig. 3). From the Otonashigawa AS, a total number of 458 grains were analyzed from the Haroku Formation, 167 grains in 2 samples from the lower part of the Lower Member and 291 grains in 3 samples from the upper part of the Lower Member to the Upper Member (Fig. 5).

\section{Results}

\section{Terasoma Formation}

Modal compositions of the sandstone from the Terasoma Formation are plotted on the QFR (quartz - feldspar rock fragments) and QPK (quartz - plagioclase - potash feldspar) ternary diagrams (Fig. 6). Almost all sandstones are wackes with more than 15\% of matrices (Okada, 1971). There are clear differences between the modal composition of sandstones from the Lower Member to the lower part of the Middle Member (T-01-08) and the upper part of the Middle Member to the Upper Member (T-09-16). The former is classified as feldspathic to lithic wackes, while the latter are only lithic wackes (Fig. 6). Moreover, the former is rich in potash feldspar and granitic rock fragments and the latter is rich in felsic volcanic rock fragments on the amount of which content increases upward.

Heavy mineral constituents of the sandstone from the Terasoma Formation are opaque mineral $(36.6 \%$, on average), euhedral zircon (34.9\%), rounded zircon (12.3\%), garnet $(8.7 \%)$, allanite $(1.7 \%)$, anatase $(1.6 \%)$, epidote $(1.1$ $\%)$, and titanite $(0.7 \%)$ with minor amounts of spinel, zoisite, rutile, barite, micas, chlorite, apatite, monazite, common hornblende, hypersthenes and moissanite. Compositions of major transparent heavy minerals are shown in Fig. 7. Heavy mineral assemblages of sandstones from the Lower Member to the lower part of the Middle Member are rich in zircon and garnet with subordinate amounts of epidote, titanite, tourmaline and allanite. Bessho (2000) named the combination of these heavy minerals as type IV. The heavy mineral assemblages of the upper part of the Middle Member and the Upper Member are rich in zircon with minor amounts of garnet and anatase (Type II). The change in the heavy mineral assemblages occurs rapidly and characteristically, with an abrupt disappearance of allanite and diminution of garnet, tourmaline, epidote and titanite.

The chemical compositions of garnets from the sandstone from the Terasoma Formation are shown in the (Sps + Grs + Adr $)-\operatorname{Prp}-$ Alm, $($ Grs + Adr $)-$ Sp $-(\operatorname{Prp}+$ Alm $)$ and $\mathrm{Mn}-\mathrm{Mg}-\mathrm{Ca}$ ternary diagrams (Teraoka et al., 1998) (Fig. 8). The almandine garnets of the Lower Member (T-a, b, c) are rich in spessartine component with some amounts of grandites. On the other hand, the Middle Member (T-d, 


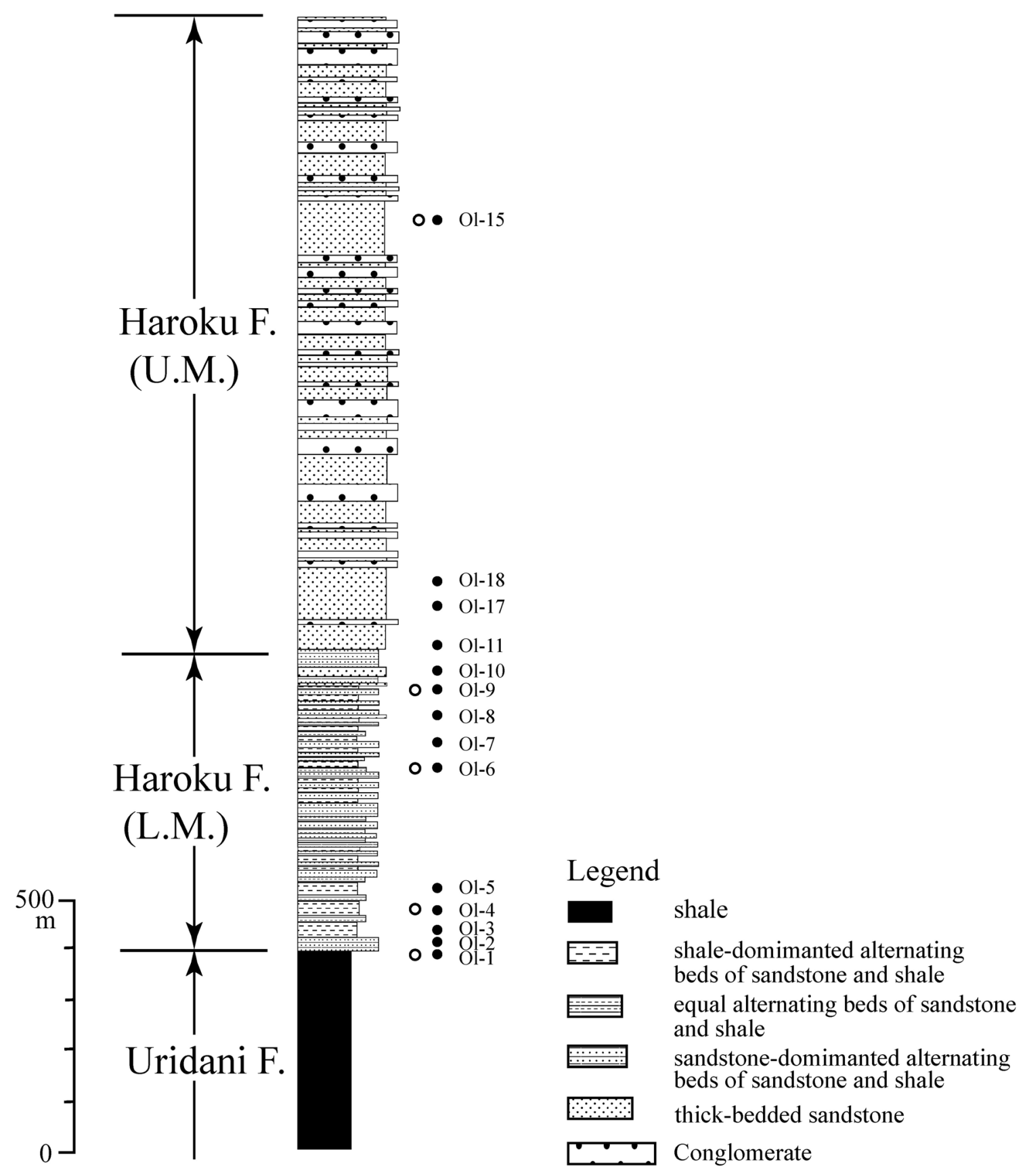

Fig. 5 Generalized columnar section of the Otonashigawa AS quoted from Nakaya (2006). Solid circles represent samples used for modal, heavy mineral analyses and open circles for garnet chemical analysis. L.M.: Lower Member, U.M.: Upper Member

e, f) is characteristically depleted in grandite garnets. In the $\mathrm{Mn}-\mathrm{Mg}-\mathrm{Ca}$ diagram, the garnets from the Lower Member are composed mainly of low $\mathrm{P} / \mathrm{T}$ (L) to intermediate $\mathrm{P} / \mathrm{T}$ (Ia) types with minor amounts of high $\mathrm{P} / \mathrm{T}(\mathrm{H})$ and grandite
(G) types. The Middle Member are predominantly low P/T (L) type with minor amounts of high $\mathrm{P} / \mathrm{T}(\mathrm{H})$ type and grandite $(\mathrm{G})$ types (Figs. 8 and 9 ). The intermediate $\mathrm{P} / \mathrm{T}$ (Ig1, Ig2) type is rarely present. 


\section{Haroku Formation in the Otonashigawa accretionary sequence}

Modal compositions of the sandstone from the Haroku Formation in the Otonashigawa AS are plotted on the QFR and QPK ternary diagrams (Fig. 10). On the basis of modal composition, the sandstones from the lower part of the Lower Member (Ol-1 to 5) are classified as feldspathic wacke or lithic wacke with average matrix content of $16.8 \%$. On the other hand, the sandstones from the upper part of the

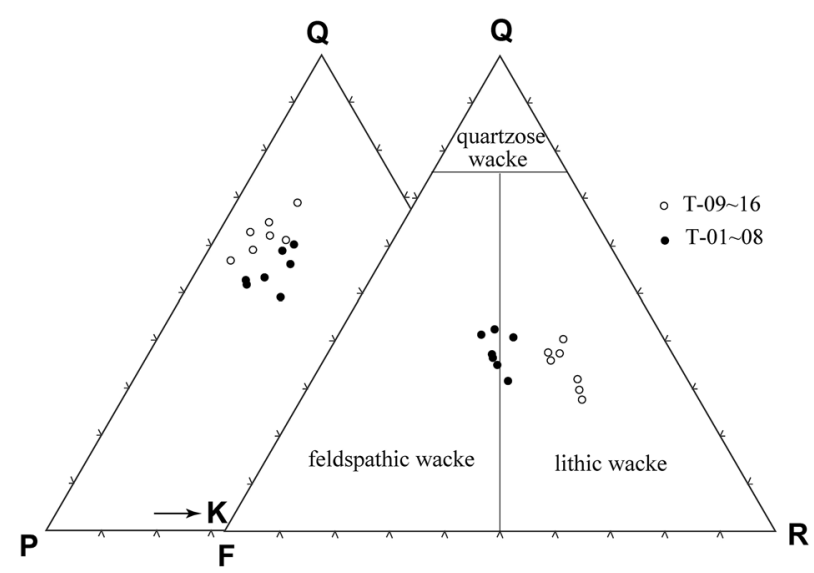

Fig. 6 Q-F-R and Q-P-K plots of the sandstone compositions from the Terasoma Formation; modified from Bessho (2004). The classification of sandstone is adopted for the Okada's scheme (Okada, 1971). Q: Quartz, F: Feldspar, R: Rock fragments, P: Plagioclase and K: Kfeldspar.
Lower Member and the Upper Member (Ol-7 to 18) are inferred to be feldspathic arenite with average matrix content of $7.3 \%$. The former is rich in felsic volcanic rock fragments and the latter is dominated by monocrystalline quartz grains.

Heavy mineral assemblages from the Haroku Formation are opaque mineral (34\%, on average), euhedral zircon (38.9 $\%)$, garnet $(13 \%)$, rounded zircon $(6.1 \%)$, allanite $(5.3 \%)$, titanite $(0.9 \%)$, epidote $(0.8 \%)$, titanite $(0.9 \%)$, chlorite $(0.9$ $\%$ ), tourmaline $(0.8 \%)$, epidote $(0.8 \%)$, rutile $(0.8 \%)$ and anatase $(0.6 \%)$ with minor amounts of barite, micas, spinel, common hornblende, zoisite, hypersthene, monazite and moissanite. Compositional ratios of transparent heavy minerals are shown in Fig. 11. Heavy mineral assemblages from the lower part of the Lower Member are composed mainly of zircon, garnet (Type II) and greenish-brown common hornblende. On the other hand, the upper part of the Lower Member and the Upper Member contain abundant allanite accompanied with epidote and titanite (Type IV) without greenish-brown common hornblende.

The chemical compositions of garnets from the Haroku Formation are plotted on 3 types of ternary diagrams (Fig. 12) similar to those in Fig. 8. The garnets of the lower part of the Lower Member $(\mathrm{Ol}-1,4)$ are dominated by pyroperich almandine of intermediate $\mathrm{P} / \mathrm{T}$ type, whereas those of the upper part of the Lower Member to the Upper Member $(\mathrm{Ol}-6,9,15)$ are almandine rich in spessartine component. A few grandites are also found in the uppermost part of the Haroku Formation. As evidenced by the $\mathrm{Mn}-\mathrm{Mg}-\mathrm{Ca}$ diagram, both low $\mathrm{P} / \mathrm{T}$ type $(\mathrm{L})$ and intermediate $\mathrm{P} / \mathrm{T}$ type garnets (Ia, Ig1, Ig2) are dominant in the former stage,

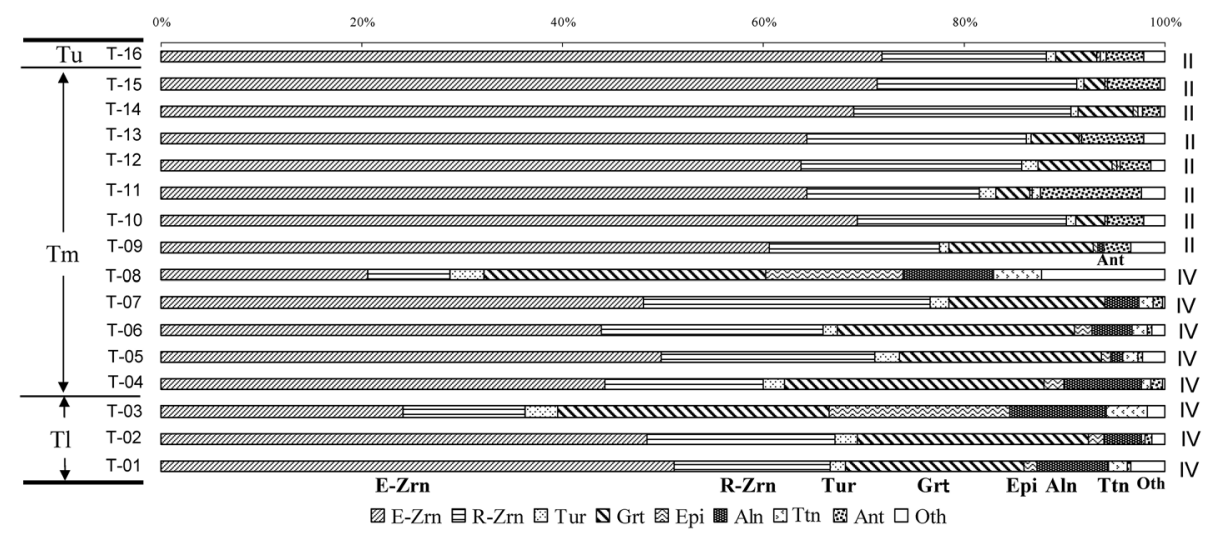

Fig. 7 Transparent heavy mineral compositions for each sample from the Terasoma Formation; modified from Bessho (2000). E-Zrn: euhedral zircon, R-Zrn: rounded zircon, Tur: tourmaline, Grt: garnet, Ep: epidote, Aln: allanite, Ttn: titanite, Ant: anatase and Oth: others. Labels II and IV indicate the heavy mineral types (Bessho, 2000). 


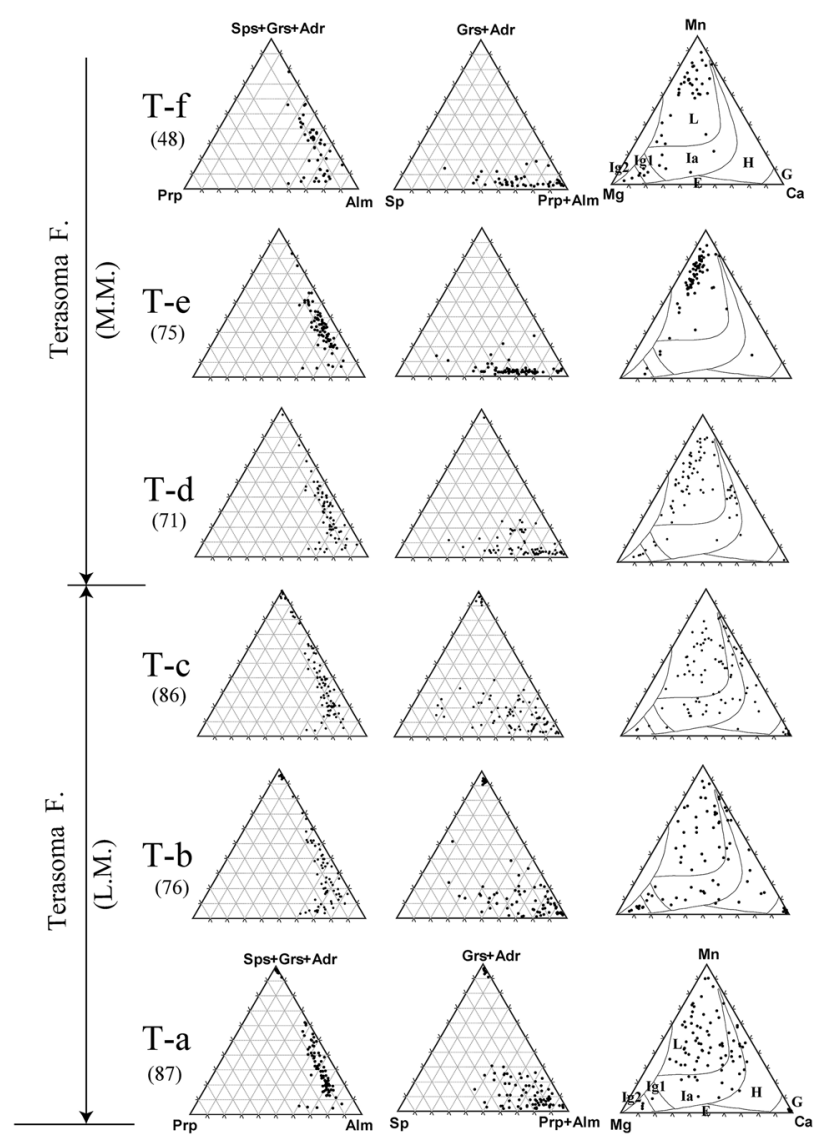

Fig. 8 Stratigraphic variations in the chemical composition of detrital garnet from the Terasoma Formation. The numerals in the parentheses show the number of grains analysed. Prp: pyrope, Alm: almandine, Sps: spessartine, Grs: grossularite, Adr: andradite, L: low P/T type, Ia, Ig1 and Ig2: intermediate $\mathrm{P} / \mathrm{T}$ type, $\mathrm{H}$ : high $\mathrm{P} / \mathrm{T}$ type, $\mathrm{E}$ : eclogite type and G: grandite Type. Type classification of garnet composition is after Teraoka et al. (1998). L.M.: Lower Member and M.M.: Middle Member.

whereas the latter stage is dominated by the abundance of low $\mathrm{P} / \mathrm{T}$ type (L) garnets (Figs. 12 and 13).

\section{Discussion}

\section{Roofing process in the Terasoma Formation}

The mid-Cretaceous Terrane arrangement of Southwest Japan is controversial (Isozaki and Itaya, 1991; Takagi and Shibata, 2000; Tazawa, 2000; Yamakita and Otoh, 2000; Yao, 2000). It is thought that the Hida-Oki and Sangun Belts, the pre-Jurassic Akiyoshi, Maizuru and Ultra-Tamba Belts and the Jurassic Mino-Tamba Belts existed to the north of the Median Tectonic Line that served as the source rocks of the Terasoma Formation (Nishimura, 1998; Takagi and Shibata, 2000; Takagi and Arai, 2003; Yamakita and Otoh, 2000). The Chichibu and Kurosegawa Belts were exposed south of the tectonic line.

The sandstone composition of the Terasoma Formation changes abruptly in the lower part of the Middle Member. The sandstones below this horizon are feldspathic and lithic wackes rich in potash feldspar and granitic rock fragments in addition to heavy minerals like allanite, epidote and titanite. These minerals and rock fragments are supposed to be derived from granitic rocks. The average amount of garnets from the sandstones below this horizon is $14.1 \%$. They are mainly composed of low $\mathrm{P} / \mathrm{T}$ (L) type with intermediate $\mathrm{P} / \mathrm{T}$ type (Ia), high P/T type (H) and grandite (G). Ig1 and Ig2 type garnets are hardly encountered. Paleocurrent analysis deduced from current structures indicates existence of the hinterland to the north (Kishu Shimanto Research Group, 1983). The origin of low $\mathrm{P} / \mathrm{T}$ (L) type garnet is considered to be low-grade metamorphic rocks and granitic rocks (Teraoka et al., 1998). The garnets from the Ryoke Belt which consists of granitoids and low-P/high-T type metamorphic complex (Okudaira, 1996) are mostly low P/T (L) type (Teraoka et al., 1997; Fig. 14d). The gravels of granitic and metamorphic rocks present from the Coniacian Matsubara and Goryo Formations which belong to the Chichibu Belt present in the north of the Terasoma Formation (Miyamoto, 1980). Considering the chemical and mineralogical characteristics of the gravels, Kano (1969, 1970) opined that these gravels might have been derived from the Ryoke Belt. However, the ages of these gravels are yet to be known. The CHIME ages of monazites from the Ryoke gneiss have been dated at 102-98 Ma, while those from western and eastern parts of the Ryoke granite have been dated at $95-85 \mathrm{Ma}$ and $92-68 \mathrm{Ma}$ respectively. It is most likely that the ages of Ryoke gneiss indicate the first attainment of lower facies and the ages of the Ryoke granite show the emplacement of the pluton (Suzuki and Adachi, 1998). Considering these age figures, it seems difficult to ascertain that Low $\mathrm{P} / \mathrm{T}$ (L) type garnet in the Lower and Middle Member of the Terasoma Fomation (Turonian to Cenomanian; 94-86 Ma) were derived from the Ryoke Belt. Teraoka et al. (1999) and Teraoka (2003) have opined that the low $\mathrm{P} / \mathrm{T}(\mathrm{L})$ type garnets in the strata deposited before the Ryoke Metamorphism were derived from the eastern Asia Continent. The Terasoma Formation deposited in forearc basin and the paleocurrent analysis suggests derivation of the sediments from northerly situated source close to the depositional basin rather than the remotely placed the eastern Asia Continent. On the other hands, the 


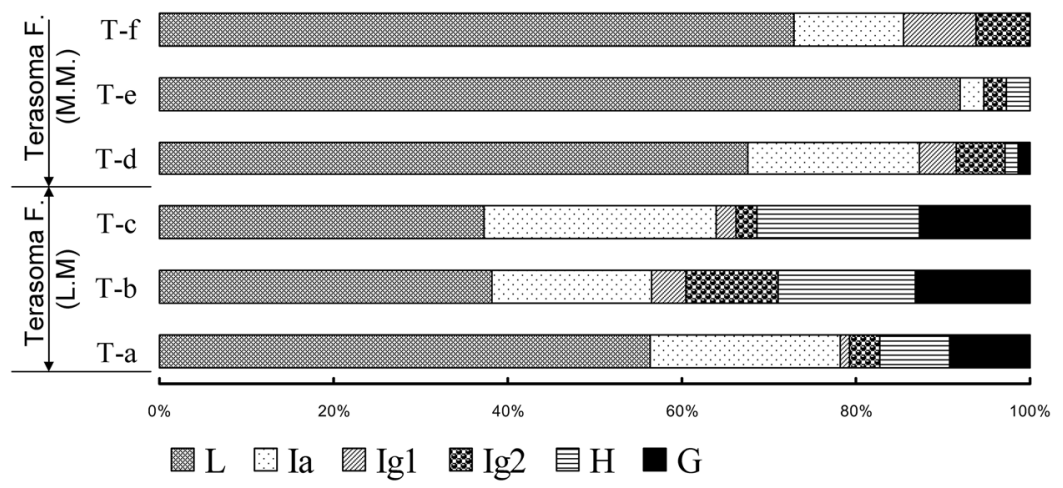

Fig. 9 Relative ratios of the compositional types of detrital garnet from the Terasoma Formation. Abbreviations are same as in Fig. 8.

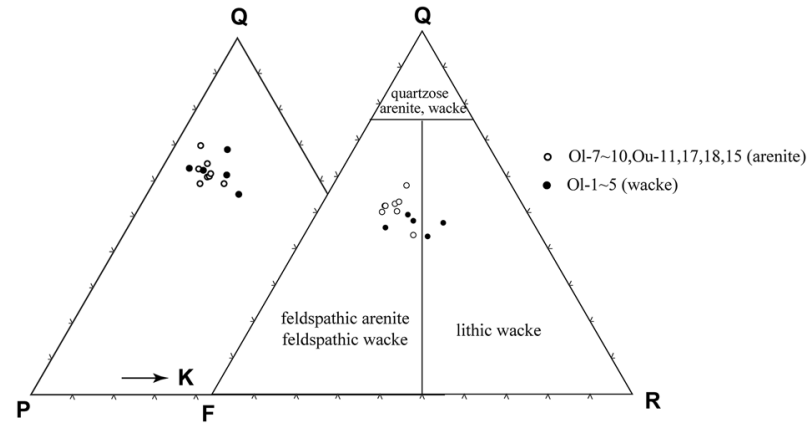

Fig. 10 Q-F-R and Q-P-K plots of the sandstone compositions from the Otonashigawa $\mathrm{AS}$; modified from Bessho and Nakaya (2011). Abbreviations are same as in Fig. 6.

Paleo-Ryoke Belt which has been supposed to exist as nappe overlying the Sambagawa and north Chichibu Belts was composed primarily of Permian granitic rocks with hornfels and mid-Cretaceous metamorphic rocks and granitic rocks (Takagi and Arai, 2003). The Permian granitic rocks, midCretaceous metamorphic rocks and mid-Cretaceous granitic rocks have been dated at 277-250 Ma (K-Ar age), 126-118 Ma (CHIME monazite age) and 113-105 Ma (K-Ar age) respectively. The garnets of the constituents of the Belt are L, Ia, Ig1 and G types (Fig. 14c). Thus, it seems reasonable to presume that the low $\mathrm{P} / \mathrm{T}(\mathrm{L})$ type garnets of the Terasoma Formation have been derived from the low $\mathrm{P} / \mathrm{T}$ metamorphic and granitic rocks of the Paleo-Ryoke Belt. Kyaw Soe Win et al. (2007) also suggested that the garnets of the Terasoma Formation are of the Paleo-Ryoke origin. The Ia and Ig1 type garnets, which are characteristic of intermediate-grade metamorphic rocks (Teraoka et al., 1998) might have been derived from the Hida, Paleo-Ryoke and the Kurosegawa Belts (Figs. 14a, b, and e). The $\mathrm{H}$ type garnets, on the other hand, are thought to have been originated from high grade metamorphic rocks (Teraoka et al., 1998) like the Hida, Sangun, Hida Marginal and Kurosegawa Belts (Figs. 14a, b, and e). The $\mathrm{H}$ type garnets of the Terasoma Formation, which contain appreciable amount of $\mathrm{Mn}$ are believed to have been derived from the metamorphic rocks of the Sangun Belt (Figs. 8 and 14b). The G type garnets originating from impure calcareous metamorphic rocks might have been derived mainly from the Hida Metamorphic Belt that contains large amount of crystalline limestone. They might also have been derived from calcareous schist of the Hida Marginal Belt and calcareous hornfels of Paleo-Ryoke Belt (Figs. 14b and c). The Ig2 type garnets, which have not been reported from the metamorphic rocks in the Japanese Islands, are present in the eastern Asian Continent of Archean age (Teraoka, 2003) suggesting that these garnets might have been derived from Precambrian gneiss in the eastern Asian Continent. Since Ig2 type garnets are common in the Terasoma Formation, but have been reported from the pre-Jurassic and Jurassic Accretionary Complexes in the Inner Zone and Chichi Belt (Teraoka, 2003), it is likely that they were reworked from these older accretionary complexes.

In the upper part of the Middle Member and the Upper Member of the Terasoma Formation, allanite suddenly disappears and epidote and titanite occur at reduced quantity. Moreover, the proportion of euhedral zircon and lithic fragments increases making the sandstones lithic wacke. These mineralogical and petrological changes in the sandstone composition possibly suggest felsic volcanism in the hinterland. This presumption is attested by the presence of intercalated felsic tuffs above the lower part of the Middle 


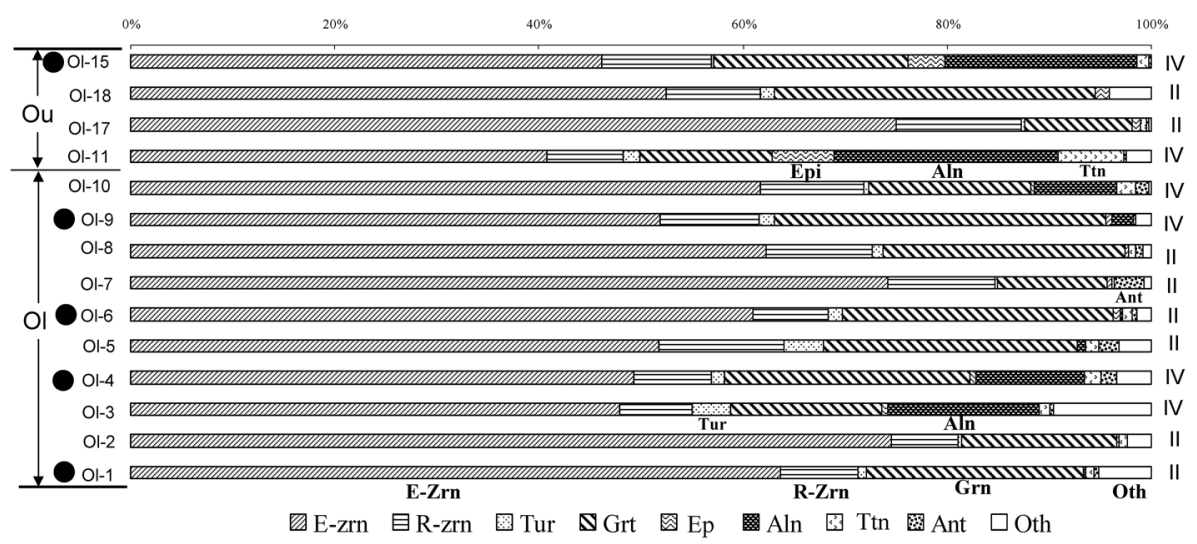

Fig. 11 Transparent heavy mineral compositions for each sample from the Otonashigawa AS; modified from Bessho and Nayaka (2011). Abbreviations are same as in Fig. 7. Solid circles represent samples used for garnet chemical analysis.

Member. The process by which the volcanic rocks cover large area of the older basement rocks is known as roofing (Kumon, 1985). The above mentioned roofing process recorded in the Terasoma Formation took place in Coniacian time and corresponds to the Late Mesozoic felsic volcanism in the Inner Zone of Southwest Japan. This volcanism was violent and massive, and its products had covered large part of the Inner Zone from Yamaguchi to Nagano prefectures. Subsequently, the products of felsic volcanism were rapidly eroded and accumulated in nearby basins. The percentage of detrital garnet rapidly decreases to as low as $3.7 \%$ after the volcanism. The proportion of intermediate $\mathrm{P} / \mathrm{T}$ (Ia), high $\mathrm{P} / \mathrm{T}(\mathrm{H})$ and grandite $(\mathrm{G})$ type garnets decrease, while the amount of low $\mathrm{P} / \mathrm{T}(\mathrm{L})$ garnets increases. Moreover, the amount of intermediate $\mathrm{P} / \mathrm{T}$ (Ia) garnet little decreases. Considering these change of garnets, it is inferred that the thick cover of volcanic products interrupted the supply of detritus from metamorphic rocks such as the Hida (Ia and G type garnets), Hida Marginal (Ia, G and $\mathrm{H}$ type garnets) and Sangun (H type garnet) metamorphic rocks. As result, the supply from the Paleo-Ryoke Belt increased resulting in frequency of low $\mathrm{P} / \mathrm{T}$ (L) type garnet (Fig. 9). The Mn content of the low $\mathrm{P} / \mathrm{T}$ (L) type garnet from the middle Member of the Terasoma Formation is larger than that of the lower Member (Fig. 8). It is a fact that the Mn contents of low $\mathrm{P} / \mathrm{T}$ (L) type garnet of pelitic gneiss, granite, and pegmatite (aplite) tend to occur in increasing order of abundance (Teraoka et al., 1997; Kyaw Soe Win et al., 2007). Hence, it is mostly likely that Mn-rich low P/T (L) type garnets from the middle Member of the Terasoma Formation were derived from the Late Mesozoic felsic volcanic rocks in the Inner Zone.

\section{Unroofing in the Otonashigawa accretionary sequence}

The west-southwesterly paleocurrents of the Otonashigawa AS suggest existence the major hinterland to the northnortheastly of depositional basin (Hatenashi Research Group, 1980). Yamakita and Otoh (2000) estimated the lateral displacement along the younger Median Tectonic Line to be about $500 \mathrm{~km}$ during late Cretaceous. Miyata et al. (1980), on the other hand, estimated the displacement of about $15 \mathrm{~km}$ during Paleogene. Hence, the terrain arrangement of southwestern Japan in the Paleogene was almost similar to that at the present. Judging from the above, the possible source rocks of the Otonashigawa AS are inferred to be: the Hida-Oki and Sangun Belts, the Akiyoshi, Maizuru and Ultra-Tamba Belts prior to Jurassic, the Jurassic Mino-Tamba Belts and Ryoke Belts in the Inner Zone, moreover, the Sambagawa, Chichibu and Kurosegawa Belts in the Outer Zone. Huge products of the Late Mesozoic felsic volcanism is thought to have broadly covered the older rocks in the Inner Zone. As mentioned previously, the sandstones from the lower part of the Lower Member are dominated by felsic volcanic fragments and contain a little greenish-brown common-hornblende. Both felsic volcanic fragments and hornblende are considered to have been derived from the Late Mesozoic felsic to intermediate volcanic and pyroclastic rocks in the Inner Zone. Garnets in the sandstones from the lower part of the Lower Member are composed mainly of low P/T (L) type with intermediate $\mathrm{P} / \mathrm{T}$ type (Ia, Ig1 and Ig2). High $\mathrm{P} / \mathrm{T}$ type (H) garnets are negligible in quantity (Fig. 12, 13). The Izumi Group (Campanian to Maastrichian) covers the Ryoke 

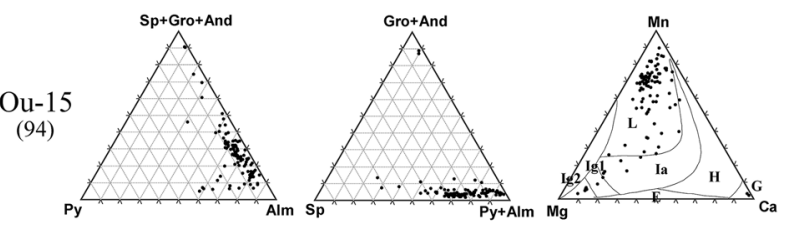

Ol-9
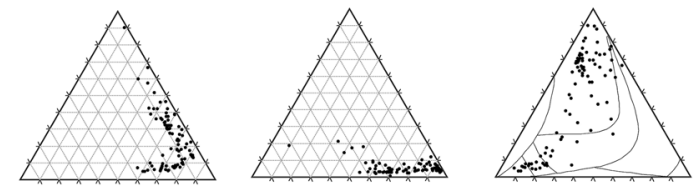

O1-6
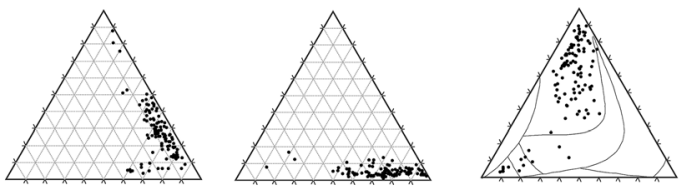

Ol-4

(76)
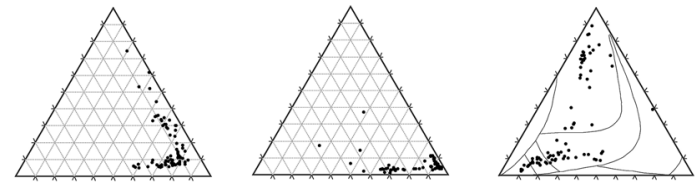

Ol-1

(91)
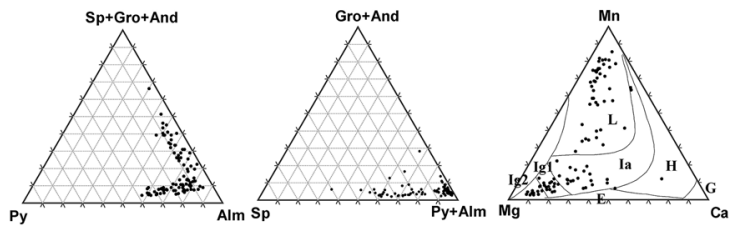

Fig. 12 Stratigraphic variations in the chemical composition of detrital garnet from the Otonashigawa AS; quoted from Bessho and Nayaka (2011). The numerals in the parentheses show the number of grains analysed. Abbreviations are same as in Fig. 8.

Belt unconformably and the garnets are mostly L type (Teraoka et al, 1998). Hence, it is supposed that the Ryoke Belt have been exposed in its southern margin at the depositional stage of the Izumi Group (Okudaira and Suda, 2011). For reasons mentioned above, Low $\mathrm{P} / \mathrm{T}$ (L) type garnets in the Haroku Formation (Paleocene to Early Eocene) were possibly derived from the Ryoke Belt. Mnrich ones in Low $\mathrm{P} / \mathrm{T}$ (L) type garnets seem to be originally from the Late Mesozoic felsic volcanic rocks in the Inner Zone. The Ia and $\operatorname{Ig} 1$ type garnets are presumed to have been derived from the Hida-Hida Marginal and Kurosegawa Belts (Fig. 14a, b, and e), while the Ig2 type garnets were supposed to have been derived from Precambrian gneiss in the eastern Asian Continent (Teraoka et al., 1999). The presence of minor amount of Ig2 type garnet might have been derived from the older accretionary complexes in the Inner Zone and the Chichi Belt by reworking (Figs. 12, 13).
$\mathrm{H}$ type garnets contained in high grade metamorphic rocks (Teraoka et al., 1998) are hardly detected. Hence, it is likely that the Sambagawa Belt which contains only garnets H type garnets (Teraoka et al., 1997) was not been exposed in the hinterland.

On the other hands, the feldspathic arenite from the upper part of the Lower Member and the Upper Member are rich in epidote, allanite and titanite (Figs. 10 and 11). Moreover, the proportion of low $\mathrm{P} / \mathrm{T}(\mathrm{L})$ type garnet increases and the one of intermediate $\mathrm{P} / \mathrm{T}$ type (Ia, $\operatorname{Ig} 1)$ garnet decreases. A few grandite are detected from the uppermost part of the Upper Member (Figs.12 and 13). Judging from the above, it is inferred that the overlying volcanic rocks and pyroclastics were removed by erosion and underlying granitic and metamorphic rocks were exposed in the hinterland. These underlying rocks are thought to be equivalent to the RyokeSanyo Granitic and Ryoke Metamorphic Rocks. This presumption is supported by the presence of clasts of granite, gneiss and hornfels in the Kizzekyo conglomerate at the top of Haroku Formation (Tokuoka, 1966). The exposure of the Ryoke Belt could be responsible for increase of low $\mathrm{P} / \mathrm{T}$ (L) type garnet and a relative decrease of Ia and Ig1 types garnet. The garnet grains of grandite are presumed to have been derived from calcareous metamorphic rocks of the Hida Belt. The Kizzekyo conglomerate also contains clasts of sandstone, chert, limestone and felsic volcanic rocks in addition to granite, gneiss and hornfels (Tokuoka, 1966). The former three are presumed to have been derived from the older accretionary complexes like the Mino-Tamba, Chichibu Belts, while the latter might have been derived from the Late Mesozoic felsic volcanic rocks in the Inner Zone. Owing to the progressive denudation and resultant exposure of deeply buried rocks known as unroofing (Groves, 1931; Mansfield, 1979), felsic volcanic products were removed and underlying granitic rocks, low $\mathrm{P} / \mathrm{T}$ metamorphic rocks, minor calcareous metamorphic rocks and sedimentary rocks cropped out in the hinterland of the Otonashigawa AS in early Eocene time. By the way, most of the sandstones of the Muro AS ranging in age from Middle Eocene to Early Miocene are richer in monocrystalline quartz than the Otonashigawa AS. The conglomerates of the Muro AS are dominated by both sedimentary and felsic volcanic rock clasts with subordinate amounts of granitic rocks (Kumon, 1983; Kumon et al., 2012). The above observations suggests that the unroofing progressed further entering into Middle Eocene.

\section{Recognition of roofing and unroofing from heavy mineral features}

As stated previously, Kumon (1985) called the event of the covering over the hinterland by huge volcanic products 


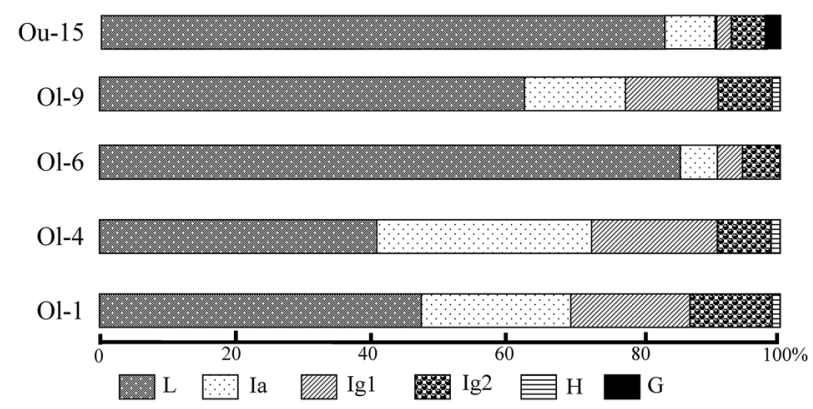

Fig. 13 Relative ratios of the compositional types of detrital garnet from the Otonashigawa AS; quoted from Bessho and Nayaka (2011). Abbreviations are same as in Fig. 8.

as roofing. On the contrary, the process that deeply buried rocks are cropped out by denudation called as unroofing (Groves, 1932; Mansfield, 1979).

As for the unroofing processes, there are the following examples made from a viewpoint of modal composition of sandstones and conglomerate composition. Mansfield (1979), while investigating the sandstone composition of the Great Valley sequence in California ranging in age from Late Jurassic to Late Cretaceous, observed that the quantity of potash feldspar and quartz increase upward at the cost of lithic fragments. He referred these changes be due to unroofing process from volcanic to plutonic rocks in a magmatic arc setting. There are following examples in Japan.

Kumon (1983) inferred unroofing from the temporal increase of quartz grains in the sandstone and gravels of older sedimentary rock and granitic rock in the Paleogene sandstones of the Shimanto Belt in the Kii Peninsula and eastern Shikoku. Kusunoki and Musashino (1989) studied the sandstones from the Tamba Belt in the Inner Zone, and found that they progressively change in composition from feldspathic- and lithic-wackes to quartz arenites from the Late Triassic to Jurassic time. They inferred that the deeperseated plutonic rocks were exposed by progressive denudation during the Middle Jurassic. Oyaizu and Kiminami (2004), who examined the Paleogene sandstones of the Shimanto Belt in western Shikoku, observed that the sandstones from the early-middle Eocene Kaji Formation are rich in felsic volcanic fragments and poor in the fragments of granitic rock, whereas those from the middlelate Eocene Inomisaki Formation are poor in felsic volcanic fragments and rich in quart and granitic rock fragments. They presumed that erosion of volcanic rocks led to the exposure of deep seated granitic rocks in the hinterland. Concerning to roofing, Kumon $(1983,1985)$ observed that the proportion of felsic volcanic rock fragments in sandstones of the Shimanto Belt in Kii Peninsula and eastern Shikoku increases upward with passage of time from Cenomanian to Turonian. He attributed this compositional change to the roofing process in the source area. Frequent intercalations of tuff layers in the Late Cretaceous strata suggest large scale volcanic activity contemporaneous with sedimentation in a forearc basin during late Cretaceous. Thus, it can be summarized that unroofing process in the present study can be inferred from the change of sandstone composition from the feldspathic-and lithic-wackes rich in felsic volcanic rock fragments to quartz arenite rich in potash feldspar and quartz grains, whereas roofing can be documented by upward increase of the proportion of felsic volcanic rock fragments.

On the other hand, systematic study of heavy minerals can be also be used as guides to roofing and unroofing events in source area. Chaundhri (1972), while investigating heavymineral assemblages of the Siwalik Formation in the northern Himarayas ranging in age from Helvetian to Cromerian, observed that heavy mineral compositions changed from staurolite to kyanite and sillimanite in ascending order. This compositional change was attributed to an exposure of deep-seated high-grade metamorphosed rocks in the source area by progressive erosion. Uddin and Lundberg (1998), who studied the heavy minerals of Upper Miocene to Pleistocene sediments in the Bengal basin, pointed out that unroofing had proceeded from the surface sedimentary rocks to deeper-seated metamorphic rocks with gradual increase of kyanite and sillimanite. Obayashi (1995) studied the chemical compositions of detrital garnets in the sandstone from Jurassic Tetori Group and the garnets which contain $30 \%$ pyrope component in average show an increase of pyrope content with time. It was inferred that the transition was due to the denudation of metamorphic rocks. As mentioned above, the temporal transition in content of specific heavy minerals like staurolite, kyanite, sillimanite or pyrope-rich almandine might be effective for recognition of unroofing. The former three minerals are rarely contained in the sandstones of the Japanese Islands. Hence, these minerals seem to be ineffective for the recognition of unroofing in the sandstones of the Japanese Islands.

In the present study, a roofing process has been indicated by the decrease of the proportion of allanite, epidote, titanite, high $\mathrm{P} / \mathrm{T}$ garnet and grandite garnet and increase in proportion of euhedral zircon and anatase in the Terasoma Formation. On the other hand, unroofing has been shown 

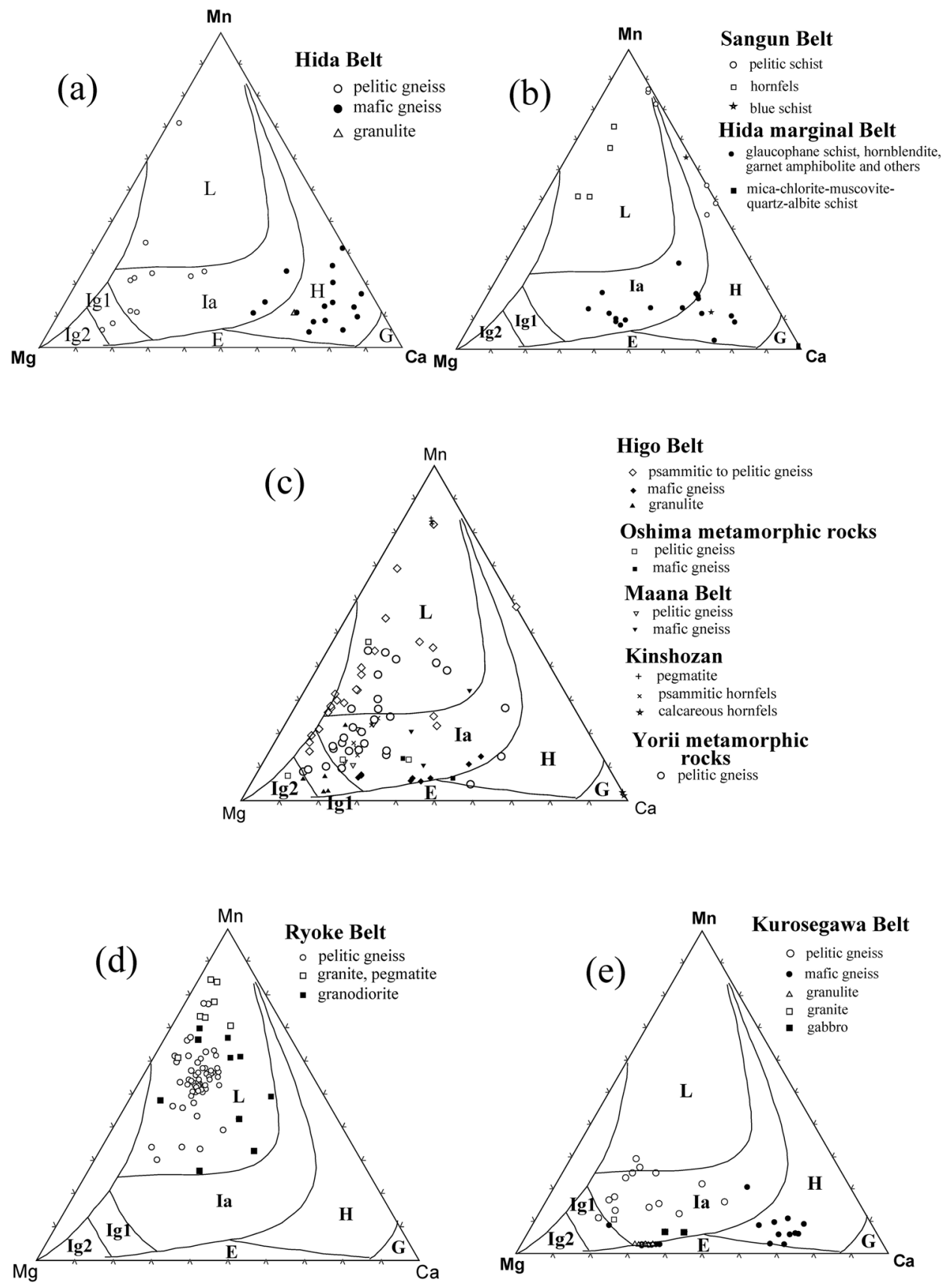

Fig. 14 Plots of garnet composition from various Belts and rocks. Sources of data: (a) Hida Belt (Asami, 1979; Hoshino, 1979; Suzuki, 1979; Suzuki and Osakabe, 1982. (b) Sangun Belt (Hashimoto, 1968; Kano, 1981; Karakida, 1987; Tsujimori, 1988), Hida marginal Belt (Banno, 1958; Ito, 1977, 1979; Miyagawa, 1982; Nakamizu et al., 1989). (c) Constituents of the Paleo-Ryoke Belt (Takagi and Shibata, 2000); Higo Belt (Karakida and Yamamoto, 1982; Maki et al., 2004; Osanai et al., 1998; Owada et al., 2005; Yamamoto, 1962; Yoshimura, 1995; Editoral Committee of Ogawa Town History, 1999), Oshima metamorphic rocks (Shikano et al., 1990), Maana Belt (Takeda et al., 1993), Kinshozan and Yorii metamorphic rocks (Arai et al., 2000; Takagi, 1991). (d) Ryoke Belt (Asami et al., 1982; Enami, 1988; Endo and Yamazaki, 2013; Ono, 1977; Nureki et al., 1982). (e) Kurosegawa Belt (Hayama, 1959, 1976; Karakida et al., 1979; Miyachi, 1969; Yoshikura, 1977, 1985; Yoshikura and Yoshida, 1979; Yoshikura et al., 1981). 
by increasing trend of allanite, epidote, titanite, spessartinerich almandine garnets (L) and grandite garnet in the Otonashigawa AS. To sum up, roofing and unroofing are especially detected by an increase or a decrease of the content of euhedral zircon, allanite, spessartine-rich almandine garnets (L), high $\mathrm{P} / \mathrm{T}$ garnet and grandite garnet. These changes of heavy mineral assemblages and the chemical compositions of detrital garnets can provide a tool to recognize roofing and unroofing processes in the volcanic arc like the Japanese Islands.

\section{Conclusions}

In addition to the traditional modal analyses, heavy mineral and garnet chemical composition analyses of sandstones were carried out on the Late Cretaceous Terasoma Formation and the Palaeogene Otonashigawa accretionary sequence, Kii Peninsula, Southwest Japan. The stratigraphic changes of modal compositons, heavy mineral assemblages and chemical composition of detrital garnets were recognized in the sequences. These changes can be ascribed to roofing and unroofing processes of their hinterlands corresponding to the sedimentation of the Terasoma Formation and the Otonashigawa accretionary sequence, respectively. Owing to the roofing formed by socalled the Late Mesozoic felsic volcanisms in the Inner zone of Southwest Japan, the modal compositions of the sandstones in the Terasoma Formation show an upward change from feldspathic wacke to lithic wacke and the heavy mineral assemblages also changed from the ones rich in allanite, epidote and titanite to the ones dominated by euhedral zircon. Moreover, the compositions of detrital garnets also show an upward change from various types (L, Ia, H, G) to L type. On the other hand, the modal compositions of the sandstones from the Otonashigawa Accretionary Sequence show an upward change from lithic wacke to feldspathic arenite. The heavy mineral assemblages also change from the ones containing greenish-brown commonhornblende to the ones dominated by allanite, epidote and titanite and the compositions of detrital garnets show an upward decrease of the pyrope-rich almandine (intermediate $\mathrm{P} / \mathrm{T}$ type) and an increase of spessartine-rich almandine (low $\mathrm{P} / \mathrm{T}$ type). Euhedral zircon, allanite, spessartine-rich almandine (L), high $\mathrm{P} / \mathrm{T}$ and grandite garnets are effective to recognize roofing and unroofing processes in the Shimanto Belt, Kii Peninsula, Japan.

\section{Acknowledgments}

The author would like to appreciate Dr. Wataru Maejima of Osaka City University for his helpful comments and encouragements throughout this work. Dr. Takamoto Okudaira of Osaka City University is thanked for facilitating the use of EDS. Thanks are also due to Dr. Fujio Kumon of Shinshu City University for his valuable comments on the earlier version of the manuscript. The manuscript benefited from constructive reviews by Dr. Kohki Yoshida of Shinshu University, Dr. Kazuo Kiminami of Yamaguchi University and an anonymous reviewer. The author is obliged to the members of the Kishu Shimanto Research Group who helped me in the field survey. Dr. Rabindra Nath Hota of Utkal University is also gratefully acknowledged for improving English.

\section{References}

Adachi, M., Suzuki, K. and Yogo, S., 1995, Examples of the analysis of orogene by CHIME geochronology. Preliminary report for a Grant-in Aid, no. 1, 16-23. (in Japanese).

Arai, H., Murakami, S. and Takagi, H., 2000, Provenance of the Atokura Formation, Kanto Mountains, central Japan. Memoires of the Geological Society of Japan, no. 56, 123-136 (in Japanese, with English Abstract).

Asami, M.,1979, Pelitic metamorphic rocks from the Arashimadake area, Toga area and Wada-gawa area of the Hida metamorphic belt. The Basement of Japanese Islands (Professor Kano Memorial Volume), 41-49 (in Japanese, with English Abstract).

Asami, M., Hoshino, M., Miyagawa, K. and Suwa, K., 1982, Metamorphic condition of staurolite schists of the Ryoke metamorphic belt in the Hazu-Hongusan area, central Japan. Journal of the Geological Society of Japan, 88, 437-450 (in Japanese, with English abstract).

Banno, S., 1958, Glaucophane schists and associated rocks of the Omi district, Niigata Prefecture, Japan. Japanese Journal of Geology and Geography, 29, 29-49.

Bessho, T., 1997, Heavy mineral composition of the Upper Cretaceous sandstones in the Shimanto Belt of the centralwestern Kii Peninsula, Southwest Japan - the Miyama, Ryujin and Nyunokawa formations - Journal of the Geological Society of Japan, 103, 377-390 (in Japanese, with English abstract).

Bessho, T., 2000, The chronological transition of heavymineral composition of the Cretaceous sandstones in the Shimanto Belt of the Kii Peninsula, Southwest Japan. Memoires of the Geological Society of Japan, no. 59, 195-210 (in Japanese, with English abstract).

Bessho, T., 2004, Transition of sandstone composition of the Cretaceous Terasoma Formation in the Shimanto Belt of the Kii Peninsula, and its significance. Journal of the Sedimentological Society of Japan, no. 60, 13-21 (in Japanese, with English abstract).

Bessho T. and Nakaya S., 2011, Unfoofing inferred from sandstone compositions of the Paleogene Otonashigawa 
Group in the Shimanto Belt of the Kii Peninsula, Southwest Japan. Journal of the Geological Society of Japan, 117, 423-438 (in Japanese, with English abstract) .

Chaudhri, R.S., 1972, Heavy minerals from the Siwalik formations of the northwestern Himalayas. Sedimentary Geology, 8, 77-82.

Deer, W.A., Howie, R.A. and Zussman, J., 1992, An Introduction to Rock Forming minerals, 2nd Ed. Pearson Education Limited, England, 696 p.

Editorial Committee of Ogawa Town History, 1999, Nature of Ogawa Town (Geology), Ogawa Town, Japan. pp. 1-283 (in Japanese).

Enami, M., 1988, Composition of garnets from the Ryoke Metamorphic Belt. Nagoya Chigaku, no. 50, 71-80 (in Japanese).

Endo, S. and Yamazaki, T., 2013, Geology of the RyokeMetamorphic Complex in the Tsukuda area, central Japan. Bulletin of Geological Survey of Japan, 64, 59-84 (in Japanese, with English abstract).

Groves, A. W., 1931, The unroofing of the Dartmoor Granite and distribution of its sediments of southern England. Quarterly Journal of the Geological Society of London, 87, 62-66, 86-94.

Hashimoto, M., 1968, Glaucophanic metamorphism of the Katsuyama district, Okayama Prefecture, Japan. Journal of the Faculty of Science, Tokyo University, Series II, 17, 99-162.

Hatenashi Reseach Group, 1980, The Otonashigawa belt of the Shimanto Terrain in the Kii Peninsula, Southwest Japan. Memoirs of Faculty of Education of Wakayama University, Natural Science, 23, 79-91 (in Japanese, with English abstract).

Hayama, Y., 1959, Gneissose garnet- amphibolites accompanied by the Mikita igneous rocks in the Kurosegawa zone of Shikoku. Journal of the Geological Society of Japan, 65, 80-89.

Hayama, Y., 1976, Re-examination of gneissose garnet amphibole from the Kurosegawa structural belt of Southwest Japan. Journal of the Geological Society of Japan, 82, 35-49.

Hoshino, M., 1979, Corundum-bearing pelitic gneiss from Dogo, Oki islands. The Basement of Japanese Islands (Professor Kano Memorial Volume), 85-88 (in Japanese, with English Abstract).

Isozaki, Y. and Itaya, T., 1991, Pre-Jurassic Klippe in northern Chichibu belt in west-central Shikoku, Southwest JapanKurosegawa terrane as a tectonic outlier of pre-Jurassic rocks of the Inner Zone. Journal of the Geological Society of Japan, 97, 431-450 (in Japanese, with English Abstract).

Ito, M., 1977, Garnets in a Quartz-bearing Garnet-Hornblende Rock from the Northwestern Part of the Asahidake Area, Hida Marginal Belt, Central Japan. Research bulletin of College of General Education, Nagoya University, 21, 69-80. (in Japanese).

Ito, M., 1979, Green mica-chlorite-muscovite-quartz-albite schist from the Asahidake area of the Hida Marginal Belt. The Basement of Japanese Islands (Professor Kano Memorial Volume), 95-100 (in Japanese, with English Abstract).

Kano, H., 1969, On the relation of the Gyliakian Urakawan granite pebbles to the Kamihara-Hiji granites in the Ryoke Belts - Studies on the granite-bearing conglomerates in Japan, No. 20-. Journal of the Geological Society of Japan, 75, 461-470 (in Japanese, with English abstract).

Kano, H., 1970, Existence of the Ryoke metamorphic rocks in the pebbles of the Lower Urakawan conglomerates in the Aritagawa district-Studies on the granite-bearning conglomerates in Japan, No. 21-. Journal of the Geological Society of Japan, 76, 143-150. (in Japanese, with English abstract).

Kano H., 1981, On the Garnets in Polymetamorphic Hornfelses from the Iba-Raizan District of the Sangun Metamorphic Belt. Scientific and Technical Reports of the Mining College, Akita University, no. 2, 23-29.

Karakida, Y., 1987, Amphiboles from the Sangun Metamorphic Rocks in the Yame Area, Fukuoka Prefecture. Memoires of Childhood Education, Seinangakuin University, 14, 55-75 (in Japanese).

Karakida, Y. and Yamamoto, H., 1982, Garnet amphibolites in the Higo metamorphic terrane, middle Kyushu. Memoires of Geological Society of Japan, no. 21, 173-187 (in Japanese, with English Abstract).

Karakida, Y., Miyachi, S., Yamamoto, H. and Oshima, T., 1979, The Kurogawa tectonic zone in Kyushu, with special reference to garnet amphibolites of Tubonokihana in the Yatsushiro district. The Basement of Japanese Islands (Professor Kano Memorial Volume), 319-340 (in Japanese, with English Abstract).

Kishu Shimanto Research Group, 1968, The study on the Shimanto terrain in the Kii Peninsula, Southwest Japan (part 2) - the present status of the research and southern formerland in Pacific Ocean. Earth Science (Chikyu Kagaku), 22, 224-231 (in Japanese, with English abstract).

Kishu Shimanto Research Group, 1970, Sedimentological and paleontological studies of the Muro Group at the southern coastal region of the Kii Peninsula - the study of the Shimanto Terrain in the Kii Peninsula, Southwest Japan (part 4). Memoirs of Faculty of Education of Wakayama University, Natural Science, 20, 75-102 (in Japanese, with English abstract).

Kishu Shimanto Research Group, 1977, The Hidakagawa Group in the southern part of the Ryujin Village, Wakayama Prefecture - the study of the Shimanto Terrain in the Kii Peninsula, Southwest Japan (part 8). Earth Science (Chikyu Kagaku), 31, 250-262 (in Japanese, with English abstract).

Kishu Shimanto Research Group, 1983, Terasoma and Shirama Formations of the Hidakagawa Group in the Shimanto Belt, Southwest Japan - the study of the Shimanto Terrain in the Kii Peninsula, Southwest Japan (part 10). Earth Science (Chikyu Kagaku), 37, 235-249 (in Japanese, with 
English abstract).

Kishu Shimanto Research Group, 1986, Miyama Formation of the Hidakagawa Group around Nakatsumura in the western part of the Kii Peninsula-the study of the Shimanto Terrain in the Kii Peninsula, Southwest Japan (part 11). Earth Science (Chikyu Kagaku), 40, 227-247 (in Japanese, with English abstract).

Kishu Shimanto Research Group, 1991, Yukawa and Miyama Formations of the Hidakagawa Group in the easternmiddle part of Wakayama Prefecture - the study of the Shimanto Terrain in the Kii Peninsula, Southwest Japan (part 12). Earth Science (Chikyu Kagaku), 45, 19-38 (in Japanese, with English abstract).

Kishu Shimanto Research Group, 2006, Geology of the Hidakagawa Belt in the central-western part of Wakayama Prefecture, Southwest Japan - the study of the Shimanto Terrain in the Kii Peninsula, Southwest Japan (part 13). Earth Science (Chikyu Kagaku), 60, 355-374 (in Japanese, with English abstract).

Kumon, F., 1983, Coarse clastic rocks of the Shimanto Supergroup in eastern Shikoku and Kii Peninsula, Southwest Japan. Memoirs of Faculty of Science, Kyoto University, Series of Geology \& Mineralogy, 49, 63-109.

Kumon, F., 1985, Stratigraphic change of the coarse clastic rocks of the Shimanto Supergroup in the eastern Shikoku, Southwest Japan. In Nasu, N., Kobayashi, K., Uyeda, S., Kushiro, I. and Kagami, H. eds., Formation of Active Ocean Margins, 819-833, Terra Scientific Publishing, Tokyo.

Kumon, F. and Kiminami, K., 1994, Modal and chemical compositions of the representative sandstones from the Japanese Islands and their tectonic implications. In Kumon, F. and Yu, K. M. eds., Proceedings of 29th International Geological Congress, Part A, 135-151, VSP, Utrecht.

Kumon, F., Bessho, T. and Roser B.P., 2012, Modal and chemical characteristics of the coarse clastic rocks from the Shimanto terrane in Kii Peninsula, Southwest Japan. Monograph of the Association for Geological Collaboration in Japan, 59, 193-216 (in Japanese, with English abstract).

Kusunoki, T. and Musashino, M., 1989, The characteristics of sandstones in the Tamba Belt, Southwest Japan. Earth Science (Chikyu Kagaku), 43, 75-83 (in Japanese, with English abstract).

Kyaw Soe Win, Takeuchi, M. and Tokiwa, T., 2007, Change in detrital garnet assemblages related to transpressive uplifting associated with strike-slip faulting:

An example from the Cretaceous System in Kii Peninsula, Southwest Japan. Sedimentary Geology, 201, 412-431.

Maki, K., Ishizaki, Y. and Nishimura, T., 2004, Staurolitebearing gneiss and re-examination of metamorphic zonal mapping of the Higo metamorphic terrane in the Kosa area, central Kyusyu, Japan. Journal of Mineralogical and Petrological Sciences, 99, 1-18.

Mansfield, C.F., 1979, Upper Mesozoic subsea fan deposits in the southern Diablo Range, California: Record of the Sierra Nevada magmatic arc. Bulletin of the Geological Society of America, Part I, 90, 1025-1046.

Miyachi, S., 1969, Almandinous pyrope in the Yatsushiro gneiss, Kumamoto Prefecture, Japan. Science Report of Faculty of Science, Kyusyu University Geology, 9, 67-72.

Miyagawa, K., 1982, Low-grade metamorphic rocks of the Hida marginal belt in the upper Kuzuryu river area, central Japan. Journal of Mineralogy, Petrology and Economic Geology, 77, 256-265.

Miyamoto, T., 1980, Stratigraphic and sedimentological studies of the Cretaceous System in the Chichibu Terrane of the Outer Zone of Southwest Japan. Journal of Science, Hiroshima University, Series C, No.3 , 1-138.

Miyata, T., Ui, H. and Ichikawa, K., 1980, Paleogene leftlateral wrenching on the Median Tectonic Line in Southwest Japan. Memoires of the Geological Society of Japan, no. $18,51-61$.

Nakamizu, M., Okada, M., Yamazaki, T. And Komatsu, M., 1989, Metamorphic rocks in the Omi-Renge serpentinite mélange, Hida Marginal Tectonic Belt, Central Japan. Memoires of the Geological Society of Japan, no. 59, 195-210 (in Japanese, with English abstract) .

Nakaya, S., 2006, Bent structure of the Paleogene Otonashigawa accretionary prism in the Kizekkyo area of the Shimanto Belt in the Kii Peninsula, Southwest Japan. Earth Science (Chikyu Kagaku), 60, 113-129 (in Japanese, with English abstract).

Nakaya, S and Sakamoto, T. 2012, Submarine Fan of the Shimanto Accretionary Prism in the Kii Peninsula. Monograph of the Association for Geological Collaboration in Japan, 59, 159-174 (in Japanese, with English abstract).

Nishimura, Y., 1998, Geotectonic subdivision and areal extent of the Sangun belt, Inner Zone of Southwest Japan. Journal of Metamorphic Geology, 16, 129-140.

Nureki, T., Asami, M., Shibata, T. and Ohira, K., 1982, The Ryoke Belt of the southwestern part of Shiaku-shoto area in the Seto-naikai Inland Sea. Journal of the Geological Society of Japan, 88, 499-510 (in Japanese, with English abstract).

Obayashi, T., 1995, Provenance nature of the Tetori Group in the Shiramine area, central Japan, based on the chemical composition of detrital garnets. Journal of the Geological Society of Japan, 101, 235-248 (in Japanese, with English abstract).

Okada, H., 1971, Again on classification and nomenclature of sandstones. Journal of the Geological Society of Japan, 77, 395-396 (in Japanese, with English abstract).

Okudaira, T., 1996, Temperature-time path for the lowpressure Ryoke metamorphism, Japan, based on chemical zoning in garnet. Journal of Metamorphic Geology, 14, 427-440.

Okudaira, T. and Suda, Y., 2011, Cretaceous events at the eastern margin of East Asia recorded in rocks of the Ryoke Belt, SW Japan. Journal of Geography, 120 452-465 (in Japanese, with English abstract). 
Ono, A., 1977, Chemical reaction at the boundary between gneiss and amphibolites in the Ryoke Metamophic Terrane at Takao, Japan. Journal of the Geological Society of Japan, 83, 33-40.

Osanai, Y., Hashimoto, T., Maishima, O and Kagami, H., 1998, Sapphirine -bearing granulites and related high-pressure metamorphic rocks from Higo metamorphic terrane, westcentral Kyusyu, Japan. Journal of Metamorphic Geology, 16, 53-66.

Owada, M., Hada, R., Yada, J., Nakamura, M. and Osanai, Y., 2005, Newly found granulites from the western part of Sefuri Mountains, North Kyushu. Journal of the Geological Society of Japan, 111, 50-53. (in Japanese, with English Abstract).

Oyaizu, A. and Kiminami, K., 2004, Provenance changes of the late Cretaceous to early Paleogene Shimanto Supergroup in western Shikoku, and its significance. Journal of the Geological Society of Japan, 110, 403-416 (in Japanese, with English abstract).

Sato, Y. and Suzuki, T., 1991, Heavy mineral analysis. Chishitu News, no. 444, 21-28 (in Japanese).

Shikano, K., Itaya, T. and Nakamura, E., 1990, Mineral assemblages and $\mathrm{K}-\mathrm{Ar}$ ages of metamorphic rocks in Oshima, Yawatahama city, Ehime Prefecture. Journal of Mineralogy, Petrology and Economic Geology, 85, 19-26.

Suzuki, H. and Nakaya, S., 2012, Evolution of the Shimanto Accretionary prism in the Kii Peninsula, Southwest Japan. Monograph of the Association for Geological Collaboration in Japan, 59, 273-282 (in Japanese, with English abstract).

Suzuki, K. and Adachi, M., 1998, Denudation history of the High T/P Ryoke metamorphic belt, Southwest Japan: Constraints from CHIME monazite ages of gneisses and granitoids. Journal of Metamorphic Geology, 16, 23-38.

Suzuki, M., 1979, Granulite-facies rocks from the Odori-river area of the western province of the Hida metamorphic belt. The Basement of Japanese Islands (Professor Kano Memorial Volume), 319-340 (in Japanese, with English Abstract).

Suzuki, M. and Osakabe, T., 1982, On the zincian spinel of the Hida metamorphic Belt, central Japan. Memoires of the Geological Society of Japan, no. 21, 37-49.

Takagi, H., 1991, Yorii metamorphic rocks -allochthonous metamorphic bodies in the northern margin of the Kanto Mountains. Part 1. Chemistry of garnet in the pelitic gneisses. Gakujyutsu Kenkyu, School of Education, Waseda University Series of Biology \& Geology, 44, 9-25 (in Japanese, with English Abstract).

Takagi, H. and Shibata, K., 2000, Constituents of the PaleoRyoke Belt and Restoration of Paleo-Ryoke and Kurosegawa Terranes. Memoires of the Geological Society of Japan, no. 56, 1-12 (in Japanese, with English Abstract).

Takagi, H. and Arai H., 2003, Restoration of Exotic Terranes. Gondwana Research, 6, 657-668.

Takeda, K., Makisaka, S., Itaya, T. and Nishimura, Y., 1993, The Maana Belt in the Mikane area, western edge of
Shikoku, Southwest Japan-composition and geotectonic setting. Journal of the Geological Society of Japan, 99, 255-279. (in Japanese, with English Abstract).

Tazawa, J., 2000, The Paleozoic of the Hida Gaien, South Kitakami and Kurosegawa Belts: Correlation and tectonic history. Memoires of the Geological Society of Japan, no. 56, 39-52 (in Japanese, with English Abstract).

Teraoka, Y., 2003, Detrital garnets from Paleozoic to Tertiary sandstones in Southwest Japan. Bulletin of the Geological Survey of Japan, 54, 171-192. (in Japanese, with English abstract).

Teraoka, Y., Suzuki, M. and Kawakami K., 1998, Provenance of Cretaceous and Paleogene sediments in the Median Zone of Southwest Japan. Bulletin of the Geological Survey of Japan, 49, 395-411 (in Japanese, with English abstract).

Teraoka, Y., Okumura, K., Suzuki, M. and Kawakami, K., 1999, Clastic sediments of the Shimanto Supergroup in Southwest Japan. Bulletin of the Geological Survey of Japan, 50, 559-590 (in Japanese, with English abstract).

Tokuoka, T., 1966, Kizekkyo Sandstone and Conglomerate of the Paleogene Muro Group in the Kii Peninsula, Japan. Memoirs of Faculty of Science, Kyoto University, Series of Geology \& Mineralogy, 32, 335-349.

Tsujimori, T., 1988, Geology of the Osayama serpentinite melange in the central Chugoku Mountains, southwestern Japan: 320 Ma blueschist-bearing serpentinite melange beneath the Oeyama ophiolite. Journal of the Geological Society of Japan, 104, 213-231.

Uddin, A. and Lundberg, N., 1998, Unroofing history of the eastern Himalaya and the Indo-Burman Ranges: heavymineral study of Cenozoic sediments from the Bengal basin, Bangladesh. Journal of Sedimentary Petrology, 68, 465-472.

Yamakita, S. and Otoh, J., 2000, Cretaceous rearrangement processes of pre-Cretaceous geologic units of the Japanese Islands by MTL-Kurosegawa left-lateral strike-slip fault system. Memoires of the Geological Society of Japan, no. 56, 23-38 (in Japanese, with English Abstract).

Yamamoto, H., 1962, Plutonic and metamorphic rocks along the Usuki-Yatsushiro Tectonic Line in the western part of central Kyusyu. Bulletin Fukuoka Gakugei University, 12, 93-171.

Yamamoto, T. and Suzuki, H., 2012, Hanazono Accretionary Complex in the northern margin of the Shimanto Belt in the Kii Peninsula, Southwest Japan. Monograph of the Association for Geological Collaboration in Japan, 59, 1-14 (in Japanese, with English abstract).

Yao, A., 2000, Terrane arrangement of Southwest Japan in view of the Paleozoic- Mesozoic tectonics of East Asia Monograph of the Association for Geological Collaboration in Japan, 49, 145-155 (in Japanese, with English abstract).

Yoshikura, S., 1977, Kurosegawa tectonic zone in central Kochi prefecture. Guidebook for excursion of $84^{\text {th }}$ Annu. Meet. Geological Society of Japan, 7, 1-42. 
Yoshikura, S., 1985, Igneous and high-grade metamorphic rocks in the Kurosegawa tectonic zone and its tectonic significance. Journal of Geosciences, Osaka City University, 28, 45-83.

Yoshikura, S. and Yoshida, M., 1979, Kurosegawa tectonic zone in the western Kii Peninsula. The Basement of Japanese Islands (Professor Kano Memorial Volume), 319-340 (in Japanese, with English Abstract).

Yoshikura, S., Shibata, K. and Maruyama, S., 1981, Garnet- clinopyroxene amphibolite from the Kurosegawa Tectonic zone, near Kochi city - Petrography and K-Ar ageJournal of the Association of Mineralogists, Petrologists and Economic Geologists, 76, 102-109.

Yoshimura Y., 1995, Compositional zoning of garnets from the Higo metamorphic belt, west-central Kyushu, Japan. Kumamoto Journal of Science, Earth Science, 14, 1-18. (in Japanese).

\section{ルーフィングとアンルーフィングは砂岩組成にどのように反映されるか？ 一紀伊半島四万十層群を例に一}

別所孝範, 2015, 堆積学研究, Vol. 74, No. 1, 3-20

Bessho, T.: How are the roofing and unroofing process reflected in sandstone composition? -A case study in the Shimanto Belt, Kii Peninsula, southwestern JapanJour. Sed. Soc. Japan, Vol. 74, No. 1, 3-20

紀伊半島四万十帯の白亜系寺杣層, 古第三系音無川付加シーケンスの砂岩組成を検討した．寺杣 層では後背地でのルーフィングに伴い, 下部から上位ヘジルコンとザクロ石に富み, 緑レン石・チ夕 ナイト・褐レン石を伴う長石質ワッケから，自形ジルコンに富む石質ワッケへと急変する．ザクロ 石は下部では様々なタイプからなるが, 上部では高圧型やグランダイトは急減し低圧型が増加する. 一方, 音無川付加シーケンスでは, アンルーフィングにより, 下部から上部にむけて緑褐色普通角閃 石を伴い自形ジルコンに富む石質ワッケから, 緑レン石・チタナイト・褐レン石に富む長石質アレナ イトへと変化する。 ザクロ石組成は上位に向けて中圧型は減少, 代わって低圧型が増加, 最上部で はグランダイトが出現する. 後背地におけるルーフィングやアンルーフィングは自形ジルコン, 褐 レン石, 低圧型・高圧型やグランダイト型ザクロ石等の消長から推定することが可能である. 